\title{
APPLICATION OF WATER EQUIVALENTS METHOD TO CALCULATIONS OF CROSS-FINNED ALUMINIUM HEAT EXCHANGERS
}

\section{Notation:}

$\alpha-$ convection heat-transfer coefficient, $\mathrm{W} /\left(\mathrm{m}^{2} \cdot \mathrm{K}\right)$

$c$ - mean heat capacity, $\mathrm{kJ} /\left(\mathrm{m}^{3} \cdot \mathrm{K}\right)$

$d$ - diameter, $\mathrm{m}$

$F$ - heating surface area, $\mathrm{m}^{2}$

$k$ - over-all heat-transfer coefficient, $\mathrm{W} /\left(\mathrm{m}^{2} \cdot \mathrm{K}\right)$

$L$ - height of fin, $\mathrm{m}$

$\lambda$ - thermal conductivity, $\mathrm{W} /(\mathrm{m} \cdot \mathrm{K})$

$m$ - parameter of fin, $m$

$N$ - Number of Heat Transfer Units

$p$ - pitch of fines, $\mathrm{m}$

$r$ - radius, $\mathrm{m}$

$s$ - thickness of fin, $\mathrm{m}$

$t$ - temperature, $\mathrm{K}$

$W_{f}-$ water equivalent of fluid, $\mathrm{W} / \mathrm{K}$

$W_{a}$ - water equivalent of air, $\mathrm{W} / \mathrm{K}$

$w$ - velocity, $\mathrm{m} / \mathrm{s}$

$V$ - volumetric rate of fluid flow, $\mathrm{m}^{3} / \mathrm{s}$

$\eta-$ heat effectives

* Ph.D.: Faculty of Metals Engineering and Industrial Computer Sciences, AGH - University of Science and Technology, Krakow, Poland; e-mail: ztc@agh.edu.pl 


\section{INTRODUCTION}

For calculation of heat exchangers designs and exploiting parameters, Mean Temperature Difference method [1, 3, 6, 7] and Number of Heat Transfer Units one [3, 6, 7] are used. Difference between methods has formal character, because both methods are based on equation of energy balance. Applying both methods it is possible to determine the heat surface area for projected heat exchangers or over-all heat-transfer coefficient for used one. The quality of NTU method is a simple algorithm of the calculation of heat transfer area which can be determined directly from NTU number. The over-all heat transfer coefficient determined resistance of heat transfer to partition wall and thermal conduction of this wall. For intensification of heat transfer surface area this wall can be finned. The aim of this paper is the presentation of the research on the reduction over-all heat transfer coefficient in heat exchanger pipe elements and application of the results in water equivalents method.

\section{OVER-ALL HEAT-TRANSFER COEFFICIENT FOR CROSS-FINNED PIPE}

The cross-finned pipe with circular fins of constant thickness illustrates Figure 1.

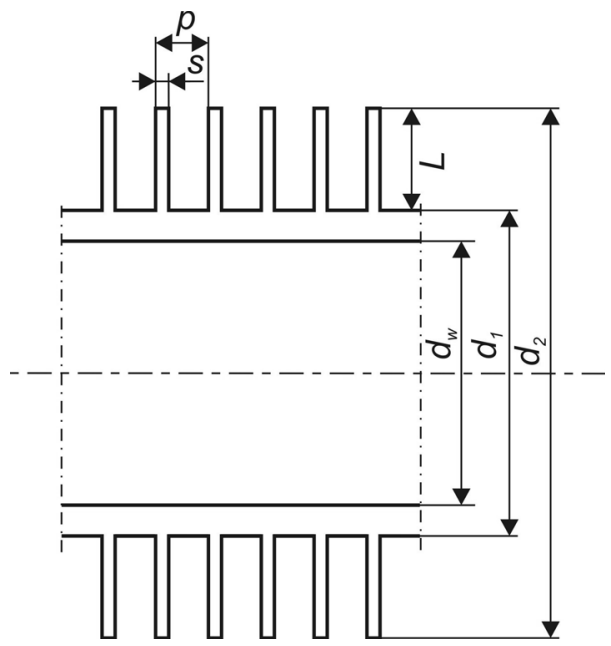

Fig. 1. The cross-finned pipe: $d_{w}$-inner diameter of pipe, $d_{1}-$ outer diameter of pipe, $d_{2}-$ outer diameter of finned pipe, $L$ - height of fin, $s$ - thickness of fin, $p$ - pitch of fines

The heat effectives for circular fin of constant thickness [8] is described by equation:

$$
\eta=\frac{1}{1+\frac{1}{3}\left(m L_{c}\right)^{2} \sqrt{\frac{r_{2 c}}{r_{1}}}}
$$


where:

$$
\begin{gathered}
r_{1}=\frac{d_{1}}{2}, \\
r_{2}=\frac{d_{2}}{2}, \\
r_{2 c}=r_{2}+\frac{s}{2}, \\
L_{c}=L+\frac{s}{2} .
\end{gathered}
$$

Parameter of fin $m$ is:

$$
m=\sqrt{\frac{2 \alpha}{\lambda s}}
$$

where:

$\alpha-$ convection of heat-transfer coefficient delivered to surface area of smooth pipe,

$\lambda-$ thermal conductivity of fin,

$s-$ thickness of fin.

The surface area of fin is:

$$
F_{\dot{z}}=2 \Pi\left(r_{2}^{2}-r_{1}^{2}\right)
$$

The surface area of smooth pipe on one pitch is:

$$
F_{r}=2 \Pi r_{1} p
$$

The inner surface area of pipe is:

$$
F_{w}=2 \Pi r_{w} p
$$

The surface area between fins on one pitch is:

$$
F_{m}=F_{r}-\Pi d_{1} s
$$

The reduction convection heat-transfer coefficient delivered to outer surface area of smooth pipe is described by equation:

$$
\alpha_{r}=\alpha\left(\frac{F_{m}}{F_{r}}+\frac{F_{\dot{z}}}{F_{r}} \eta\right)
$$


The convection heat-transfer coefficient delivered to outer surface area of pipe is:

$$
\alpha_{a}=\left(3.57+0.0017 \bar{t}_{a}\right) \frac{w_{a}^{0.8}}{d_{1}^{0.2}}
$$

The convection heat-transfer coefficient to inner surface area for water is:

$$
\alpha_{f}=3373\left(1+0.014 \bar{t}_{f}\right) w_{f}^{0.8}
$$

for light oil is:

$$
\alpha_{f}=349\left(1+0.014 \bar{t}_{f}\right) w_{f}^{0.8}
$$

for heavy oil is:

$$
\alpha_{f}=169\left(1+0.014 \bar{t}_{f}\right) w_{f}^{0.8}
$$

The reduction over-all heat-transfer coefficient delivered to outer surface area of smooth pipe is described by equation:

$$
\frac{1}{k_{r}}=\frac{r_{1}}{r_{w} \alpha_{f}}+\frac{r_{1}}{\lambda} \ln \frac{r_{1}}{r_{w}}+\frac{1}{\alpha_{r}}
$$

\section{SIMILARITY FUNCTION USED TO CALCULATIONS OF CROSS-FLOW HEAT EXCHANGERS}

The Water Equivalents Method is the most universal method of calculation. It can be applied to determine design and using parameters of heat exchangers [3, 7]. This method is based on the concept of water equivalent and heat effectives. Fluid-gas water equivalent of fluid for heat exchangers is described by equation:

$$
W_{f}=V_{f} c_{f}
$$

where:

$V_{f}-$ volumetric rate of fluid flow,

$c_{f}-$ mean heat capacity of fluid.

The water equivalent of air is:

$$
W_{a}=V_{a} c_{a}
$$


where:

$V_{a}$ - volumetric rate of air flow,

$c_{a}$ - mean heat capacity of air.

Similarity functions used for heat exchangers are described by equals:

$$
\begin{aligned}
& \varepsilon=f\left(\frac{W_{f}}{W_{a}}, N\right) \\
& \varepsilon=\frac{t_{a}^{\prime \prime}-t_{a}^{\prime}}{t_{f}^{\prime}-t_{a}^{\prime}}
\end{aligned}
$$

where:

$t_{a}^{\prime \prime}$ - outlet air temperature,

$t_{a}^{\prime}$ - inlet air temperature,

$t_{f}^{\prime}$ - inlet fluid temperature,

$N$ - Number of Heat Transfer Units.

The Number of Heat Transfer Units is described by equation:

$$
N=\frac{k F}{W_{a}}
$$

With equation (17) it is possible to calculate heat surface area:

$$
F=\frac{N W_{a}}{k_{r}}, \quad W_{a}<W_{f}
$$

Similarity function used in cross-flow heat exchangers illustrate Figure 2 and Figure 3.

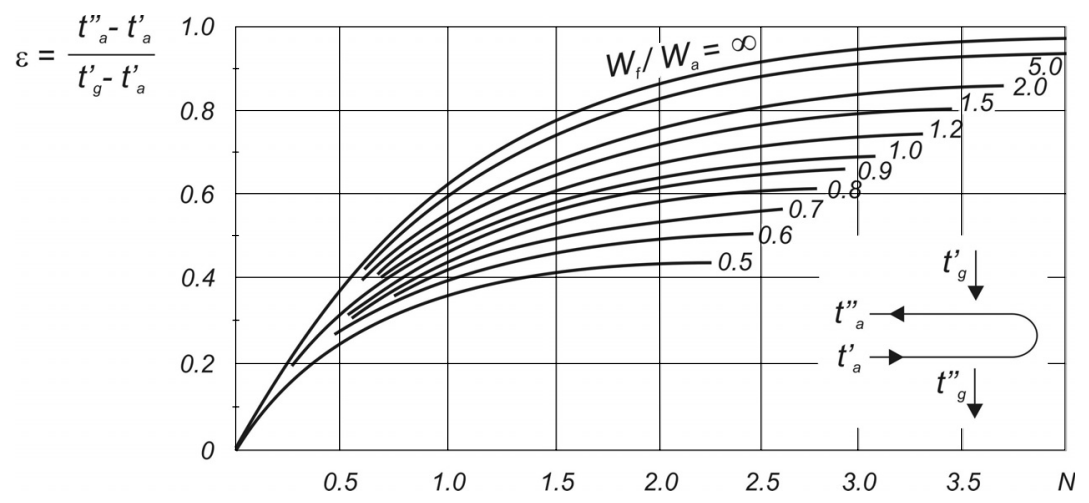

Fig. 2. Similarity function $\varepsilon=f\left(\frac{W_{f}}{W_{a}}, N\right)$ used in cross-flow heat exchangers (counter-flow) 


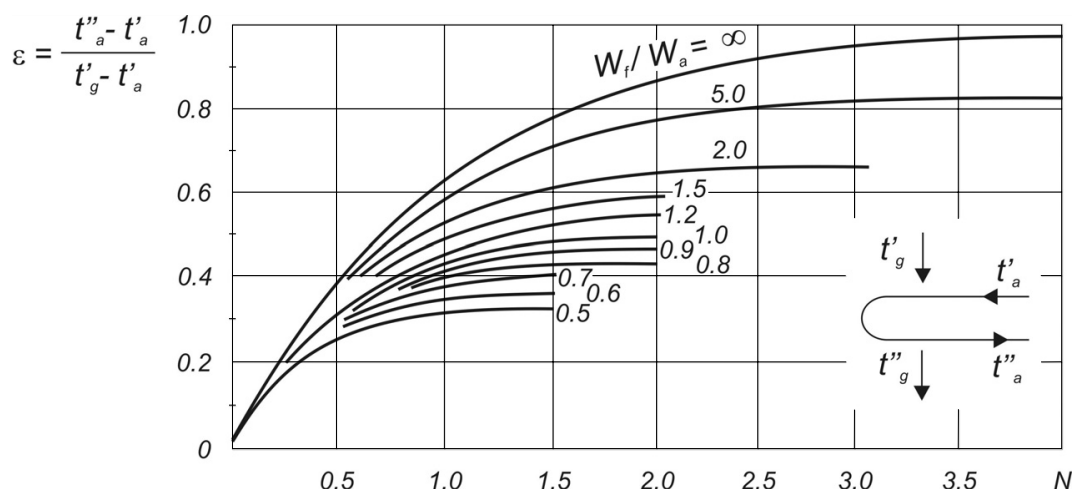

Fig. 3. Similarity function $\varepsilon=f\left(\frac{W_{f}}{W_{a}}, N\right)$ used in cross-flow heat exchangers (parallel-flow)

\section{RESEARCH OF REDUCTION \\ OVER-ALL HEAT-TRANSFER COEFFICIENT}

The tested element of heat exchangers has the following geometric, flow and temperature parameters:

- inner diameter of element

$d_{w}=0.025 \mathrm{~m}$,

- outer diameter of element

$d_{1}=0.030 \mathrm{~m}$,

- outer diameter of finned element

$d_{2}=0.052 \mathrm{~m}$,

- height of fin

$L=0.011 \mathrm{~m}$,

- thickness of fin

$s=0.00045 \mathrm{~m}$,

- pitch of fin

$p=0.00252 \mathrm{~m}$,

- inlet air temperature

$t_{a}^{\prime}=18.3^{\circ} \mathrm{C}$,

- outlet air temperature

$t_{a}^{\prime \prime}=23.5^{\circ} \mathrm{C}$,

- inlet oil temperature

$t_{f}^{\prime}=70.1^{\circ} \mathrm{C}$,

- outlet oil temperature

$t_{f}^{\prime \prime}=66.6^{\circ} \mathrm{C}$,

- volumetric rate of oil flow

$V_{f}=0.35 \mathrm{~kg} / \mathrm{s}$,

- volumetric rate of air flow

$V_{a}=0.365 \mathrm{~m}^{3} / \mathrm{s}$,

- surface area of air flow

$F_{a}=0.00317 \mathrm{~m}^{2}$.

The velocity of air is:

$w_{a}=\frac{V_{a}}{F_{a}}=\frac{0.365}{0.00317}=11.5 \mathrm{~m} / \mathrm{s}$. 
The heat effectives of fin is:

$$
\eta=\frac{1}{1+\frac{1}{3}\left(m L_{c}\right)^{2} \sqrt{\frac{r_{2 c}}{r_{1}}}}
$$

where:

$$
\begin{aligned}
& r_{1}=\frac{d_{1}}{2}=\frac{0.030}{2}=0.015 \mathrm{~m}, \\
& r_{2}=\frac{d_{2}}{2}=\frac{0.052}{2}=0.026 \mathrm{~m}, \\
& r_{2 c}=\frac{d_{2}+s}{2}=\frac{0.052+0.00045}{2}=0.0264 \mathrm{~m} .
\end{aligned}
$$

The parameter of fin is:

$$
m=\sqrt{\frac{2 \alpha}{\lambda s}}=\sqrt{\frac{2 \cdot 45.4}{165 \cdot 0.00045}}=34.96 \mathrm{~m}
$$

where:

$$
\begin{aligned}
& \alpha_{a}=\left(3.5+0.00185 \bar{t}_{a}\right) \frac{w_{a}^{0.8}}{d_{2}^{0.2}} \\
& \bar{t}_{a}=\frac{18.3+23.5}{2}=20.9{ }^{\circ} \mathrm{C} \\
& \mathrm{d}_{2}=0.052 \mathrm{~m}, \\
& \alpha_{a}=(3.5+0,00185 \cdot 20.9) \frac{11.5^{0.8}}{0.052^{0.2}}=45.4 \mathrm{~W} /\left(\mathrm{m}^{2} \cdot \mathrm{K}\right) .
\end{aligned}
$$

The thermal conductivity of aluminium $\lambda=165 \mathrm{~W} /(\mathrm{m} \cdot \mathrm{K})$.

The over height of fin is:

$$
\begin{aligned}
& L_{c}=L+\frac{s}{2}=0.011+0.00045=0,0112 \mathrm{~m}, \\
& m \cdot L_{c}=34.96 \cdot 0.0112=0.392 \mathrm{~m}^{2}
\end{aligned}
$$

The effectives of fin is:

$$
\eta=\frac{1}{1+\frac{1}{3}\left(m L_{c}\right)^{2} \sqrt{\frac{r_{2 c}}{r_{1}}}}=\frac{1}{1+\frac{1}{3}(0.392)^{2} \sqrt{\frac{0.0264}{0.015}}}=0.93
$$


The surface area of fin is:

$$
F_{\dot{z}}=2 \Pi\left(r_{2}^{2}-r_{1}^{2}\right)=2 \Pi\left(0.026^{2}-0.015^{2}\right)=0.00283 \mathrm{~m}^{2} .
$$

The surface area of smooth pipe on one pitch is:

$$
F_{r}=2 \Pi r_{1} p=2 \Pi \cdot 0.015 \cdot 0.00254=0.000239 \mathrm{~m}^{2} .
$$

The inner surface area of pipe is:

$$
F_{w}=2 \Pi r_{w} p=2 \Pi \cdot 0.012 \cdot 0.00254=0.00191 \mathrm{~m}^{2} .
$$

The surface area between fins on one pitch is:

$$
F_{m}=F_{r}-\Pi d_{1} s=0.000239-\Pi \cdot 0.030 \cdot 0.00045=0.000197 \mathrm{~m}^{2}
$$

The reduction convection heat-transfer coefficient is:

$$
\alpha_{r}=\alpha\left(\frac{F_{m}}{F_{r}}+\frac{F_{\dot{z}}}{F_{r}} \eta\right)=45.4\left(\frac{0.000197}{0.000239}+\frac{0.00283}{0.000239} \cdot 0.93\right)=536.6 \mathrm{~W} /\left(\mathrm{m}^{2} \cdot \mathrm{K}\right) .
$$

\subsection{The calculation of heat-transfer coefficient to laminar flow by water equivalents method}

For heat exchanger working in laminar flow on account of lack the good calculation formulas, the real problem is to determine convection heat transfer coefficient from fluid to wall of elements. In working heat exchanger with known heat surface area, over-all heattransfer coefficient by NTU method can be calculated by equation:

$$
k_{r}=\frac{N W_{a}}{F}
$$

The reduction convection heat transfer coefficient is described by equation:

$$
\alpha_{f}=\frac{1}{\frac{r_{w}}{r_{1}}\left(\frac{1}{k_{r}}-\frac{1}{\alpha_{r}}-\frac{r_{1}}{\lambda} \ln \frac{r_{1}}{r_{w}}\right)}
$$

The heat effectives is:

$$
\varepsilon=\frac{t_{a}^{\prime \prime}-t_{a}^{\prime}}{t_{f}^{\prime}-t_{a}^{\prime}}=\frac{23.5-18.3}{70.1-18.3}=0.10
$$


The water equivalent of oil is:

$W_{f}=V_{f} \rho_{f} c_{f}=0.35 \cdot 1920=672 \mathrm{~W} / \mathrm{K}$,

where:

mean heat capacity of oil $\quad c_{f}=1920 \mathrm{~J} /(\mathrm{kg} \cdot \mathrm{K})$,

density of oil $\quad \rho_{f}=864 \mathrm{~kg} / \mathrm{m}^{3}$.

The water equivalent of air is:

$W_{a}=V_{a} c_{a}=0.365 \cdot 1280=467.2 \mathrm{~W} / \mathrm{K}$,

where:

mean heat capacity of air $\quad c_{a}=1280 \mathrm{~J} /\left(\mathrm{m}^{3} \cdot \mathrm{K}\right)$.

The simplex of water equivalents is:

$\frac{w_{f}}{w_{a}}=\frac{672.0}{467.2}=1.44$

The Number of Heat Transfer Units $N=0.10$.

For heat surface area of exchanger $F=1.15 \mathrm{~m}^{2}$ the value of reduction over-all heat transfer coefficient is:

$$
k_{r}=\frac{N W_{a}}{F}=\frac{0.1 \cdot 467.2}{1.15}=40.6 \mathrm{~W} /\left(\mathrm{m}^{2} \cdot \mathrm{K}\right) .
$$

The reduction convective heat-transfer coefficient is:

$$
\begin{aligned}
\alpha_{f} & =\frac{1}{\frac{r_{w}}{r_{1}}\left(\frac{1}{k_{r}}-\frac{1}{\alpha_{r}}-\frac{r_{1}}{\lambda} \ln \frac{r_{1}}{r_{w}}\right)}=\frac{1}{\frac{0.012}{0.015}\left(\frac{1}{40.6}-\frac{1}{536.6}-\frac{0.015}{165} \ln \frac{0.015}{0.012}\right)}= \\
& =54.9 \mathrm{~W} /\left(\mathrm{m}^{2} \cdot \mathrm{K}\right) .
\end{aligned}
$$

Hence the reduction over-all heat-transfer coefficient is:

$$
\begin{aligned}
& \frac{1}{k_{r}}=\frac{r_{1}}{r_{w} \alpha_{f}}+\frac{r_{1}}{\lambda} \ln \frac{r_{1}}{r_{w}}+\frac{1}{\alpha_{r}}=\frac{0.015}{0.012 \cdot 54.9}+\frac{0.015}{165} \ln \frac{0.015}{0.012}+\frac{1}{572.9}=0.0245 \\
& k=40.8 \mathrm{~W} /\left(\mathrm{m}^{2} \cdot \mathrm{K}\right) .
\end{aligned}
$$

\section{INFERENCES}

- The research and calculation make possible the identification of reduction over-all heat-transfer coefficient for heat exchangers element, made of aluminium alloy. 
- The reduction over-all heat-transfer coefficient is described by: convection heat-transfer coefficient from element to air, convection heat-transfer coefficient from fluid to wall, thermal conductivity of wall and geometric dimensions of element.

- The reduction convection heat-transfer coefficient to air is a function of: heat-transfer coefficient to air calculated for surface area of smooth element, the simplex of fin surface area and surface area of smooth element and the fin effectives.

- The reduction over-all heat-transfer coefficient can be used for calculation surface area of heat exchanger for determined flow, temperature and geometric parameters by water equivalents method.

\section{Acknowledgements}

The financial support from the Polish Ministry of Science and Higher Education, contract AGH No. 11.11.110.865 is gratefully acknowledged.

\section{REFERENCES}

[1] Karczewski K.: Wpływ mikroużebrowania powierzchni równoległoprądowych rekuperatorów metalowych na ich cechy konstrukcyjne i eksploatacyjne, UWN-D AGH, Kraków, 2000

[2] Karczewski K.: Metallurgy and Foundry Engineering, 29 (2003), 97-107

[3] Karczewski K.: Obliczenia cieplne rekuperatorów metalowych dla pieców przemysłowych, UWN-D AGH, Kraków, 2004, SU 1667

[4] Karczewski K.: Metallurgy and Foundry Engineering, 33 (2007), 129-139

[5] Karczewski K.: Metallurgy and Foundry Engineering, 34 (2008), 39-50

[6] Mikheyev M.: Fundamentals of Heat Transfer. Mir Publishers, Moscow 1968

[7] Senkara T.: Obliczenia pieców grzewczych w hutnictwie żelaza, Wyd. Śląsk, Katowice, 1983

[8] Taler J., Duda P.: Rozwiązywanie prostych i odwrotnych zagadnień przewodzenia ciepła, WNT, Warszawa 2003

Received

June 2010 